\begin{tabular}{|c|c|c|}
\hline Silit & $\begin{array}{c}\text { Türkiye Tarımsal Araştırmalar Dergisi } \\
\text { dergipark.org.tr/tutad }\end{array}$ & $\begin{array}{l}\text { Turk J Agric Res } \\
\text { 2021, 8(1): 1-11 } \\
\text { (C) TÜTAD } \\
\text { ISSN: 2148-2306 }\end{array}$ \\
\hline 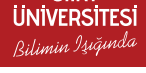 & Araştırma Makalesi / Research Article & $\begin{array}{l}\text { e-ISSN: } 2528-858 \mathrm{X} \\
\text { doi: } 10.19159 / \text { tutad.742929 }\end{array}$ \\
\hline
\end{tabular}

\title{
Karabuğday (Fagopyrum esculentum Moench) Bitkisinden Hazırlanan Silaj Örneklerinin Kalitesi Üzerine Etkili Olan Laktik Asit Bakteri Profilinin DNA Parmak İzi Tekniği ile Tanımlanması
}

\author{
Çiğdem YAMANER ${ }^{*}$, Mehtap ALKAN² ${ }^{2}$ Ebru ARSLAN HALAVURT ${ }^{3}$, Taha Harun TEKİN ${ }^{3}$ \\ ${ }^{1}$ Isparta Uygulamalı Bilimler Üniversitesi, Ziraat Fakültesi, Tarımsal Biyoteknoloji Bölümü, Isparta, TÜRKIYYE \\ ${ }^{2}$ Bolu Abant İzzet Baysal Üniversitesi, Ziraat Fakültesi, Bitki Koruma Bölümü, Bolu, TÜRKIYE \\ ${ }^{3}$ Adnan Menderes Üniversitesi, Ziraat Fakültesi, Tarımsal Biyoteknoloji Bölümü, Aydın, TÜRKIYYE
}

\begin{tabular}{|c|c|}
\hline Geliș Tarihi/Received: 26.05 .2020 & Kabul Tarihi/Accepted: 04.02 .2021 \\
\hline \multicolumn{2}{|l|}{ ORCID ID (Yazar sirasina göre / by author order) } \\
\hline (D)orcid.org/0000-0001-5140-2059 (D) orcid.org/0000-0002-79 & id.org/0000-0002-0987-4682 (D) orcid.org/0000-0003-0223-1649 \\
\hline
\end{tabular}

Öz: Bu çalışmada, Türkiye'nin Ege Bölgesi’nde yer alan Aydın Adnan Menderes Üniversitesi Ziraat Fakültesi deneme alanında yetiştirilen karabuğday (Fagopyrum esculentum Moench)'dan hazırlanan silaj örneklerindeki laktik asit bakteri (LAB) profillerinin M13 ve (GTG)5 tekrarlı dizi primerleri ile PCR-DNA-parmak izi tekniği kullanılarak belirlenmesi ve baskın suşlar hakkında veri elde edilmesi hedeflenmiştir. Çalışmada, farklı kuru madde (KM) içeriklerine sahip karabuğday örneklerine 2 farkl konsantrasyonda $\left(1.5 \times 10^{5}-1.5 \times 10^{6} \mathrm{kob} \mathrm{g}^{-1}\right)$ inokulant ve 2 farklı konsantrasyonda $\left(4-6 \mathrm{~L} \mathrm{t}^{-1}\right)$ formik asit ilave edilerek hazırlanan 15 farklı silaj örneği kullanılmıştır. İlk olarak 15 farklı silaj örneğinin KM, pH ve Fleig puanları, daha sonra bu örneklerin toplam LAB sayıları ve LAB'ların cins düzeyinde çeşitliliği belirlenmiştir. Silaj örneklerinden laktik asit bakterileri olduğu tespit edilen 50 izolat elde edilmiș ve LAB çeșitliliğini tür düzeyinde tespit etmek amaciyla (GTG)5 ve M13 primerleri kullanılarak bu izolatların Polimeraz Zincir Reaksiyonu (PZR) parmak izi profilleri elde edilmişsir. Çalışmada kullanılan 50 LAB izolatı için M13 primeri ile toplamda 52 lokus, (GTG)5 primeri ile 39 lokus üretilmiștir. Markör [M13 ve (GTG)5] sistemi, farklı LAB türlerine ait izolatlar arasında önemli bir değişkenlik sağlayan çok sayıda fragment üretmiştir. Kluster ve ayrım gücü analizi sonuçlarına göre silaj örneklerinin LAB profilinin moleküler karakterizasyonu için her iki primerin de [M13 ve (GTG)5] kullanılması gerektiği belirlenmiştir. Farklı KM oranına (\% 20, \% 30, \% 40) sahip örnekler mikrobiyal çeşitlilik ve kalite açısından incelendiğinde, \% $30 \mathrm{KM}$ içeriği ön plana çıkmaktadır. Çalışmada, \% 30 ve \% $40 \mathrm{KM}$ içerikli örneklerde Enterococcus sayısının artması ve buna paralel olarak silaj kalitesinin de artması silaj kalitesi üzerine Enterococcus sayısının etkili olabileceğini göstermektedir. Bu çalışmada elde edilen izolatlardan iki tanesinin silaj starteri olabilme potansiyeli bulunmaktadır. Bu veriler ışığında \% $30 \mathrm{KM}$ içeren karabuğday silajının yüksek LAB çeşitliliğine sahip kaliteli bir silaj ve alternatif kaba yem olacağı söylenebilir.

Anahtar Kelimeler: Silaj, karabuğday, DNA-parmak izi, Enterococcus, formik asit

\section{Identification of Lactic Acid Bacterial Profile Effective on the Quality of Silages Prepared from Buckwheat (Fagopyrum esculentum Moench) by DNA Fingerprinting Techniques}

\footnotetext{
Abstract: In this study, it was aimed to obtain data about dominant strains and to determine lactic acid bacteria (LAB) profile in the silage samples prepared from buckwheat (Fagopyrum esculentum Moench), grown in fields of the Faculty of Agriculture of Aydın Adnan Menderes University in Turkey's Aegean region, by using PCR-DNA-fingerprinting technique through M13 and (GTG) 5 repeating sequence primers. In the study, 15 different silage samples prepared by adding 2 different concentrations $\left(1.5 \times 10^{5}-1.5 \times 10^{6} \mathrm{cfu} \mathrm{g}^{-1}\right)$ of inoculant and 2 different concentrations $\left(4-6 \mathrm{~L} \mathrm{t}^{-1}\right)$ of formic acid to buckwheat samples with different dry matter (DM) contents were used. First, DM, pH and Fleig points of 15 different silage samples, then total LAB numbers and the variety of LABs at genus level of these samples were determined. 50 isolates which were detected to be LAB
} 
from silage samples were obtained and Polymerase Chain Reaction (PCR) fingerprint profiles of these isolates were obtained using primers (GTG) 5 and M13 to detect LAB variety at species level. For the 50 LAB, a total of 52 loci with the M13 primer and 39 loci with the (GTG)5 primer were produced. The markers [M13 and (GTG)5] produced many different fragment profiles. According to the results of cluster and separation analysis, it was determined that both primers [M13 and (GTG)5] should be used for molecular characterization of LAB, isolated from silage samples. When samples with different DM ratio $(20 \%, 30 \%, 40 \%)$ were examined in terms of microbial diversity and quality, $30 \%$ DM content came into prominence. The rise of the number of Enterococcus in samples with $30 \%$ and $40 \%$ DM content and the increase in silage quality in parallel shows that Enterococcus number can be effective on silage quality. Two of the isolates obtained in this study have the potential to become a silage starter. In the light of these data, it can be said that buckwheat silage containing $30 \%$ DM will be a quality silage with high LAB diversity and an alternative roughage.

Keywords: Silage, buckwheat, DNA-fingerprinting, Enterococcus, formic acid

\section{Giriș}

Türkiye'de son yıllarda hayvancılığın gelişmesi ile birlikte hayvan sayısının artması kaliteli kaba yem ihtiyacını gündeme getirmiştir. Kaba yemler, koyun, sığır, keçi ve manda gibi geviş getiren hayvanların beslenmesinde oldukça önemlidir. Geviş getiren hayvanların sindirim sistemleri kaba yemi en iyi şekilde sindirebilecek yapıdadır. Diğer yandan kaliteli kaba yem açığının giderilmesi amacı ile yem hammadde ithalatı hayvancılık sektöründe maliyetlerin artmasına neden olmaktadır (Özkan, 2020).

Karabuğday (Fagopyrum esculentum Moench) bitkisi mevcut üretilen kaba yemlere önemli bir alternatif oluşturmaktadır. Son yıllarda ruminant rasyonlarında karabuğdayın taze, silaj ve tane gibi farklı formları kullanılmaya başlanmıştır (Amelchanka ve ark., 2010; Keleş ve ark., 2018). Leiber ve ark. (2012), rumen fermantasyonu üzerine karabuğdayın etkilerini incelendikleri çalıșmalarında; karabuğdayın içerdiği fenolik bileșikler nedeni ile rumende mikrobiyal popülasyonu etkilemeden metan gazı oluşumunu düşürdüğünü belirlemişlerdir.

Türkiye'de kaba yem üretimi yanında, elde edilen yemlerin muhafazası da büyük önem arz etmektedir. Bu amaçla yemlerin silolanmaları, kaba yem muhafazasında uygulanan önemli bir yöntemdir. Silaj bir yem kaynağı olup; tarım atıkları, yeşil yem (su içeriği $>$ \%50) ve bitkisel ürünlerin fermantasyonu sonucu elde edilmektedir. Yani hayvanlar için suca zengin yemlerden hazırlanan bir çeşit turşudur. Silolama öncesinde, bitki materyali çok çeşitli mikroorganizmaları içermesine rağmen (Fabiszewska ve ark., 2019), fermantasyon işlemi laktik asit bakterileri (LAB)'nin çoğalmasını destekler. LAB, Enterococcus, Lactobacillus, Lactococcus, Leuconostoc, Pediococcus, Weissela ve Streptococcus gibi çeşitli cinslerden bakterileri içermektedir (Vandamme ve ark., 2014). Silaj fermantasyonu anaerobik koşullarda gerçekleşmektedir. Silolama esnasında LAB, karbonhidratların organik asitlere dönüşümünü sağlamaktadırlar.

Son yıllarda, silaj kalitesini arttırabilmek ve yem kaybını en aza indirebilmek için çeşitli katkı maddeleri kullanılmaktadır. Bu katkı maddeleri arasinda Lactobacillus, Pediococcus ve Enterococcus cinsi mikroorganizmalar gibi laktik asit bakterilerini içeren inokulantlar yer almaktadır (Vandamme ve ark., 2014).

Yapılan çalışmalarda LAB inokulantları; silaj pH'sın1, bütrik asit, asetik asit, amonyak azotu $\left(\mathrm{NH}_{3}-\mathrm{N}\right)$ ve etanol düzeylerini düşürürken, laktik asit/asetik asit ile laktik oranını arttırdığ1, ayrıca Lactobacillus'ların sayıca artmasını teşvik ederek silaj fermantasyonunu geliştirdiği tespit edilmiştir (Weinberg ve ark., 1993; Stokes ve Chen, 1994; Moran ve ark., 1996; Meeske ve ark., 1999; Filya ve ark., 2000; Filya, 2002a, 2002b). Söz konusu inokulantlar silajların aerobik stabilitelerini ise bazen arttırırlarken (Moran ve ark., 1996), bazen etkilememekte (Filya, 2001, 2002b) ve bazen ise düşürmektedirler (Weinberg ve ark., 1993; Filya, 2002b).

Silajın mikrobiyal ekolojisi ve silolama esnasında mikroorganizmaların işlevleri hakkında çok çeşitli çalışmalar olmasına rağmen, halen elde edilen bilgiler sınırlıdır (McAllister ve ark., 2017). Bunun yanında silaj örneklemesi, metot seçimi, Polimeraz Zincir Reaksiyonu (PZR) tekniklerinde kullanılacak primer seçimine kadar pek çok aşamada sınırlamalar olmasına rağmen, moleküler biyolojideki gelişmeler silajın mikrobiyal ekolojisinin anlaşılmasında devrim yaratacağ düşünülmektedir.

Son zamanlarda, bakteriyel suşların genetik yapısına göre ayırt edilmesi, yüksek ayrım gücü nedeniyle yaygın olarak kullanılmaktadır. Bir suşun belirli bir genotiplendirme yöntemiyle elde edilen genetik profili, parmak izi kadar benzersiz olabilmektedir. Bakterilerin genetik materyali içerisinde doğal olarak bulunan, tekrarlayan DNA dizisi bulunmaktadır. $\mathrm{Bu}$ diziler genom üzerinde çok sayıda kopya halinde dağılmış bir şekilde 
yerleşmiştir. $\mathrm{Bu}$ dağınık tekrarlayan DNA elementlerinin fonksiyonları hala bilinmemekle birlikte, bunların varlığ izlerinin ortaya konulması için kullanışlı parametrelerdir (Li ve ark., 2009).

Bu çalışmada, Türkiye'nin Ege Bölgesi'nde yer alan Aydın Adnan Menderes Üniversitesi Ziraat Fakültesi deneme alanlarında yetiştirilen karabuğday ( $F$. esculentum Moench)'lardan hazırlanan silaj örneklerindeki laktik asit bakteri profillerinin M13 ve (GTG)5 tekrarlı dizi primerleri ile PCR-DNA-parmak izi tekniği kullanılarak belirlenmesi ve baskın suşlar hakkında veri elde edilmesi hedeflenmiştir.

\section{Materyal ve Yöntem}

\subsection{Materyal}

$\mathrm{Bu}$ çalışmada; Aydın Adnan Menderes Üniversitesi Ziraat Fakültesi $\left(37^{\circ} 45^{\prime} \mathrm{N}, 27^{\circ} 45^{\prime} \mathrm{E}\right.$; $38 \mathrm{~m})$ deneme alanlarında ekimi yapılan karabuğday ( $F$. esculentum Moench) bitkisinden "TUBITAK-1120896" no'lu proje kapsamında, Zootekni Bölümü'nde hazırlanan silaj örnekleri materyal olarak alınmıştır (Keleş ve ark., 2018). Tarımsal Biyoteknoloji laboratuvarına getirilen 15 farklı 3 farklı kuru madde (KM) x 5 farklı katk1 maddesi (2 katk1 maddesinin dozları ve kontrol)] silaj örneği laktik asit bakteri izolasyonu ve kalite parametreleri incelenmesi amacı ile kullanılmıştır. $\mathrm{Bu}$ çalışmada kullanılan örneklerin hazırlanmasında katk1 maddesi olarak $1.5 \times 10^{5} \mathrm{kob}$ $\mathrm{g}^{-1}$ ve $1.5 \times 10^{6} \mathrm{kob} \mathrm{g}^{-1}$ konsantrasyonlarında laktik asit bakteri inokulant1, $4 \mathrm{~L}^{-1}$ ve $6 \mathrm{~L}^{-1}$ konsantrasyonlarında formik asit kullanılmıştır.

Karabuğday silajı hazırlamada ilave edilen inokulant kompozisyonu: Lactobacillus buchneri LN4637, ATCC PTA-2494, Lactobacillus plantarum LP 286, DSM 4784 ATCC 53187, Enterococcus faecium EF301 DSM 4789 ATCC $55593\left(2 \times 10^{9} \mathrm{kob} \mathrm{g}^{-1}\right)$ 'dur.

\subsection{Karabuğday silaj örneklerinde kuru madde, pH ve Fleig puanı değerlerinin belirlenmesi}

Kuru madde oranlarının hesaplanması amacı ile 5 gramlık karabuğday silaj örnekleri darası alınmış kaplar içerisinde etüve yerleştirilmiştir. Sabit ağırlığa ulaşıncaya kadar $105{ }^{\circ} \mathrm{C}$ 'de kurutulmuş, desikatörde soğutulup tartımları yapıldıktan sonra gerekli hesaplamalarla KM değerleri belirlenmiştir (Akyıldız, 1984). pH değeri, pH metre (HANNA HI 2211) kullanılarak ölçülmüştür.

Silaj örneklerinin pH değerleri ile KM oranları kullanılarak Eşitlik 1 yardımı ile Fleig puanı (FP) hesaplanmıştır (Kılıç, 1986).
$\mathrm{FP}=[220+(2 \times$ silaj KM oran1-15) $]-40 \times \mathrm{pH}$

\subsection{Karabuğday silaj örneklerinden laktik asit bakterilerinin izolasyonu}

Laktik asit bakterisi sayımı amacıyla, 10 g'lık silaj örneği $90 \mathrm{ml} \%$ 0.1'lik peptonlu suya aktarılmış ve Lab-Blenderı ile homojenize edildikten sonra desimal dilüsyonlar hazırlanmıștır. Uygun dilüsyonlardan alınan 1 ml'lik örnekler, Lactobacillus'ların izolasyonu için De Man-Rogosa ve Sharpe Agar'a (MRS Agar) (Merck-millipore), Streptococcus ve Lactococcus cinslerinin izolasyonu için M17 Agar'a (Merck-millipore) ve Enterococcus cinsi için Kanamycin Esculin Azide Agar (Merck-millipore) besiyerlerine dökme plak yöntemine göre üç paralelli ekimleri yapılmıştır. İnokulasyon sonrası MRS Agar içeren petriler 30 ${ }^{\circ} \mathrm{C}$ 'de, M17 agar içeren petriler $35{ }^{\circ} \mathrm{C}$ 'de ve Kanamycin Esculin Azide Agar içeren petriler 42 ${ }^{\circ} \mathrm{C}$ 'de 3-5 gün inkübe edilmiştir. İnkübasyon süresi sonunda laktik asit bakterisi sayımı yapılmıştır (Bulut, 2003). Tüm mikrobiyolojik sayım sonuçları $\mathrm{kob} \mathrm{g}^{-1}$ olarak ifade edilmiştir. Örneklerdeki laktik asit bakterilerinin izolasyonu amaciyla, sayım yapilan MRS, M17 ve Kanamycin Esculin Azide Agar petrilerinden, koloni sayısının karekökü kadar koloni, tanımlama amacıyla seçilmiştir. (Hounhouigan ve ark., 1993). Seçilen bu laktik asit bakterisi izolatlarının saflıklarını belirlemek amaciyla, MRS ve M17 Agar petrilerine çizme plak yöntemine göre ekimler yapıldıktan sonra izolatlar inkübatörde üremeye bırakılmıştır. Üreme süresi sonrasında petrilerde oluşan kolonilerin kültürel ve morfolojik özellikleri incelenmiştir. Morfolojik inceleme amaciyla izolatlara Gram boyama (Harrigan ve McCance,1976) ve katalaz testleri uygulanmıştır. Gram-pozitif ve katalaz negatif sonuç veren izolatlar, şüpheli laktik asit bakterisi olarak değerlendirilmiştir.

\subsection{Karabuğday silaj örneklerinden izole edilen laktik asit bakterilerinin DNA'larının izolasyonu}

Karabuğday silaj örneklerinden izole edilen ve laktik asit bakterisi olduğu biyokimyasal testler ile belirlenen izolatların DNA izolasyonları Bakteri Genomik DNA izolasyon kiti (Thermo Fisher ${ }^{\circledR}$ Products \& Kits) kullanılarak gerçekleştirilmiştir.

\section{5. (GTG)5, M13 parmak-izi analizi}

Çalışmada kullanılan karabuğday silaj örneklerinden izole edilen ve laktik asit bakterisi olduğu tespit edilen 50 farklı izolatın genomik DNA izolasyonu gerçekleştirilmiştir. Elde edilen DNA'lar da (GTG)5 ve M13 tekrar serileri PZR ile çoğaltılarak parmak-izi profilleri oluşturulmuştur. (GTG)5 ve M13 tekrar serilerinin çoğaltılmasında 
kullanılan PZR karışımında, $4 \mu \mathrm{l}$ master mix ( 5 *FIREPolR Master Mix/ SOLIS Bio Dyne), 0.75 $\mu l$ primer (GTG5 5-GTGGTGGTGGTGGTG- 3 ve M13 5-GAGGGTGGCGGTTCT-3), $2 \mu$ DNA ve toplam hacim $20 \mu$ l olacak şekilde steril ultra saf su kullanılmıştır. PZR işleminde gradient PZR cihazı (Techne, UK) kullanılmış ve LAB'leri için $94{ }^{\circ} \mathrm{C} 2$ dakika ön denatürasyon, 40 çevrim, $94^{\circ} \mathrm{C} 1$ dakika, $42{ }^{\circ} \mathrm{C} 20$ saniye, $72{ }^{\circ} \mathrm{C} 2$ dakika ve $72{ }^{\circ} \mathrm{C} 10$ dakika olarak gerçekleştirilmiştir. PZR ürünleri eletroforez sisteminde (Thermo) \% 1'lik agaroz jel kullanılarak yürütülmüştür ve jel görüntüleme sisteminde bant profilleri gruplandırılmıştır.

Markörlerden elde edilen veri matrisi, NTSYSPC versiyon 2.02 programı (Rohlf, 2000) ile Jaccard'ın benzerlik kat sayısı kullanılarak genetik benzerlik matrisine çevrilmiştir. Benzerlik matrisi ağırlıklı olmayan aritmetik ortalama eş grup metodu (UPGMA) yardımıyla kümeleme analizi yapılarak dendrogram elde edilmiş ve izolatlar arasındaki genetik akrabalık değerlendirilmiştir. İzolatlar arasındaki genetik yakınlı $\% 80$ benzerlik katsayısına göre hesaplanmıştır.

\section{Bulgular ve Tartışma}

\subsection{Karabuğday silaj örneklerinin kuru madde ve $\mathbf{p H}$ değerleri}

$\mathrm{Bu}$ çalışma kapsamında 15 farklı karabuğday silaj örneği kullanılmıştır. Farklı kuru madde içeriklerine sahip örneklerin $\mathrm{pH}$ ve fleig puanları uygulamalara göre farklılık göstermiştir. Buna göre $\% 20$ kuru maddeli ve herhangi bir uygulama yapılmayan kontrol grubunda $\mathrm{pH}$ değeri 4.8 iken, bu değer \% $30 \mathrm{KM}$ oranına sahip kontrol grubunda 4.7, \% $40 \mathrm{KM}$ oranına sahip kontrol gurubunda ise 4.3 olduğu tespit edilmiştir. Kuru madde oranından bağımsız olarak silaj yapımında farklı oranlarda (4-6 $\left.\mathrm{L} \mathrm{t}^{-1}\right)$ asit ilave edilmesi, elde edilen silaj örneklerinin pH değerini 4.1'e kadar düşürmüştür. Örneklerin hazırlanmasında bakteriyal inokulant ilave edilen gruplarda $\mathrm{pH}$ değeri ise $\mathrm{KM}$ oranlarına göre değişiklik göstermiştir. Buna göre \% $20 \mathrm{KM}$ içeren örneklerde $\mathrm{pH}$ 5.3'e kadar yükselirken, \% 30 ve $\% 40 \mathrm{KM}$ oranına sahip örneklerde sırası ile $\mathrm{pH}$ 4.5 ve 4.2 'ye kadar düşmüştür (Tablo 1 ).

Silaj katkı maddesi olarak kullanılan inokulantların başarısı pek çok faktöre bağlıdır. Bu faktörler arasında silolanacak bitki materyalinin çeşidi ve özellikleri, klimatik koşullar, epifitik mikroflora, silolama tekniği ve inokulantın özellikleri yer almaktadır (Henderson ve McDonald, 1984). Silaj yapımında LAB inokulantının ilavesi, fermentasyon sürecinde laktik asit oranının hızlı bir şekilde artması, silaj pH'sının düşmesi ve yemin korunması amacı ile yapılmaktadır (Filya ve ark., 2000). Fakat bazı araştırmalarda ise LAB inokulant ilavesinin aerobik stabiliteyi azalttığı rapor edilmiştir (Weinberg ve ark., 1993). Bu çalışma kapsamında \% $20 \mathrm{KM}$ içerikli yem örneğine inokulant ilavesinin $\mathrm{pH}$ 'yı düşürmediği, kontrol grubunda $\mathrm{pH} 4.8$ iken, inokulant ilavesi ile bu değerin 5.3'e kadar yükseldiği görülmektedir. Çalışmada, \% $20 \mathrm{KM}$ içeren karabuğday silajlarının LAB inokulantı ilavesine rağmen kalitesinin düşük olduğu, fakat KM içeriğinin artmasına paralel olarak silaj kalitesinin yükseldiği görülmüştür. Merry ve ark. (1993) yaptıkları çalışmada mikrobiyal inokulantın başarılı olabilmesinin bitkisel materyalin suda çözünür karbonhidrat içeriği ve KM bileşimi ile bağlantılı olduğunu göstermiştir. Muck (2004) yaptıkları çalışmada düşük KM içerikli (\% 17.3, \% 24.6 ve \% 26.3) misır bitkisinin silajı için iki farklı inokulant (birincisi Propionibacterium jensei, Pediococcus pentosaceus içerirken; ikincisi Enterococcus faecium, Lactobacillus plantarum içermektedir) ilavesinin kontrol grubuna göre silaj

Tablo 1. Çalışmada kullanılan silaj örneklerine ait kuru madde, $\mathrm{pH}$ ve Fleig puanları

\begin{tabular}{|c|c|c|c|c|c|c|}
\hline Örnek kodu & Silaj KM & Katk1 & Katk1 oran1 & Taze KM & $\mathrm{pH}$ & FP \\
\hline 1 & 20 & Kontrol & Katk1s1z & 23.8 & 4.8 & 53 \\
\hline 2 & 20 & Bakteri & $1.5 \times 10^{5} \mathrm{kob} \mathrm{g}^{-1}$ & 23.9 & 5.1 & 41 \\
\hline 3 & 20 & Bakteri & $1.5 \times 10^{6} \mathrm{kob} \mathrm{g}^{-1}$ & 23.3 & 5.3 & 33 \\
\hline 4 & 20 & Formik asit & $4 \mathrm{~L} \mathrm{t}^{-1}$ & 23.4 & 4.1 & 81 \\
\hline 5 & 20 & Formik asit & $6 \mathrm{~L} \mathrm{t}^{-1}$ & 23.7 & 4.2 & 77 \\
\hline 6 & 30 & Kontrol & Katk1sız & 34.8 & 4.7 & 77 \\
\hline 7 & 30 & Bakteri & $1.5 \times 10^{5} \mathrm{kob} \mathrm{g}^{-1}$ & 34.8 & 4.5 & 85 \\
\hline 8 & 30 & Bakteri & $1.5 \times 10^{6} \mathrm{kob} \mathrm{g}^{-1}$ & 33.4 & 4.5 & 85 \\
\hline 9 & 30 & Formik asit & $4 \mathrm{~L} \mathrm{t}^{-1}$ & 33.2 & 4.1 & 101 \\
\hline 10 & 30 & Formik asit & $6 \mathrm{~L} \mathrm{t}^{-1}$ & 33.9 & 4.1 & 101 \\
\hline 11 & 40 & Kontrol & Katk1sız & 41.7 & 4.3 & 113 \\
\hline 12 & 40 & Bakteri & $1.5 \times 10^{5} \mathrm{kob} \mathrm{g}^{-1}$ & 41.2 & 4.2 & 117 \\
\hline 13 & 40 & Bakteri & $1.5 \times 10^{6} \mathrm{kob} \mathrm{g}^{-1}$ & 40.9 & 4.2 & 117 \\
\hline 14 & 40 & Formik asit & $4 \mathrm{~L} \mathrm{t}^{-1}$ & 41.5 & 4.1 & 121 \\
\hline 15 & 40 & Formik asit & $6 \mathrm{~L} \mathrm{t}^{-1}$ & 40.9 & 4.1 & 121 \\
\hline
\end{tabular}


pH'larını değiştirmediğini tespit etmiştir. Bitki materyalindeki karbonhidrat konsantrasyonuna bağlı olarak pH'daki düşüşün hızı da yavaşlayabilmektedir. Aerobik mikroorganizmalar tarafından ortamdaki suda çözünür karbonhidratların kullanılması silo içerisinde Clostridial aktiviteyi başlatmaktadır. Enterobacteria'lar, maya ve küfler sayıca artmaya başlar ve silajda bütrik asit fermantasyonu önlenemez. Bunun sonucunda da silajlar bozulur (Filya ve ark., 2000). Bingöl ve ark. (2008) çalışmalarında düşük kaliteli silajların kalitesini arttırabilmek için \% 5 melas ilave ederken, Dumlu ve ark. (2013) ise yonca bitkisini 8 saat soldurarak KM içeriğini arttırmışlardır. Her iki yöntemde silaj kalitesini arttırmayı başarmıştır. Karabuğday silajında da dışarıdan karbonhidrat kaynağı ilave edilmeden KM içeriğinin yükseltilmesi sonucunda silajın kalitesinin arttığı bu çalışma ile gözlemlenmiştir.

Çalışmada, \% $40 \mathrm{KM}$ ve asit uygulaması içeren grup fleig puanı en yüksek olan grup (121) iken, $\% 20 \mathrm{KM}$ ve bakteriyal inokulant uygulaması yapılan grubun fleig puanı en düşük grup (33) olduğu tespit edilmiştir (Tablo 1). Örneklerin KM ve $\mathrm{pH}$ değerlerine göre hesaplanan fleig puanları, yüksek KM ve düşük $\mathrm{pH}$ değerlerine sahip olan silajlarda yüksek bulunmuştur. Kaliteli bir silajda pH 4.5'ten küçük (Tan ve Serin, 2008), KM \% 3040 ve FP 61-100 arasında olması (Altınok ve ark., 2005) gerekmektedir. Bu özellikler silaj yapımında en yaygin kullanılan misirda ortalama olarak $\mathrm{pH}$ 3.8, KM \% 31 ve FP 100 (Altınok ve ark., 2005), pH 3.50-3.63 (Özyazıcı ve ark., 2018); sorgumda KM \% 20.1 ve pH 3.90 (Arslan ve Çakmakç1, 2011), FP 86.72 (Alçiçek ve ark., 1999), pH 3.603.95 (Özyazıcı ve ark., 2018); tritikalede pH 4.2, KM \% 42.6 ve FP 120.8 (Kara ve ark., 2009); dallı darı (Panicum virgatum L.) bitkisinde çeşitlere göre pH 3.84-4.86, KM \% 39.0-51.0 ve FP 88.6-144.7 (Eliş ve Özyazıc1, 2019) olarak rapor edilmiştir. Bulgularımızda \% $30 \mathrm{KM}$ içeren karabuğday silajı örneğinin $\mathrm{pH}$ değeri, KM oranı ve FP bakımından kaliteli olduğu belirlenmiştir. Silajı yapılan farklı KM oranlarına sahip karabuğdayın $\mathrm{pH}$ değeri ve fleig puanları yukarıdaki araştırmalarla karşılaştırıldığında \% 20 KM karabuğday silajının incelenen özellikler bakımından oldukça düşük değerlere ve düşük silaj kalitesine sahip olduğu belirlenmiştir.

\subsection{Karabuğday silajı örneklerindeki LAB yoğunluğu ve çeşitliliği ile örneklerin KM oranı ve pH arasındaki ilişki}

$\mathrm{Bu}$ çalışma kapsamında üç farklı oranda KM ( $\%$ 20, \% 30 ve \% 40) içeren ve iki farklı uygulamanın (inokulant ve asit ilaveli) farklı dozları ile hazırlanan 15 farklı karabuğday silaj örneği, üç farklı besiyeri kullanılarak mikrobiyolojik açıdan incelenmiştir. Ayrıca LAB çeşitliliği ile oranları birbirleriyle karşılaştırılmıştır (Tablo 2). MRS Agar kullanılarak yapılan LAB sayım sonuçlarına bakıldığında, silaj yapılacak ürünün KM içeriği ile LAB sayısının orantılı olduğu görülmektedir. Çalışmada \% $20 \mathrm{KM}$ içeriğine sahip ham madde kullanılarak hazırlanan silajda LAB sayısı $2.3 \log$ kob g $^{-1}$ iken, \% $40 \mathrm{KM}$ içeriğine sahip ham madde kullanılarak hazırlanan silajda LAB sayısının $7.47 \log \mathrm{kob} \mathrm{g}^{-1}$ olduğu tespit edilmiştir. Bakteri inokulantı ilavesi toplam LAB içeriğini arttırıyorken, asit uygulamasının bakteri sayısını arttırmadığı hatta \% $40 \mathrm{KM}$ içerikli silaj örneğinde bakteri sayısının 7.47 log kob g ${ }^{-1}$ den, $3.95 \log \mathrm{kob}$ $\mathrm{g}^{-1}$ 'e düştüğü gözlenmiştir (Tablo 2). Filya ve Sucu (2004) yapmış oldukları mısır silajına formik asit ilavesinin Lactobacilli sayısını 7.6 log kob g ${ }^{-1}$ 'dan

Tablo 2. Farklı kuru madde içerikli ve farklı uygulamaların olduğu silaj örneklerinin LAB içeriği

\begin{tabular}{|c|c|c|c|c|c|}
\hline \multirow[b]{2}{*}{ Örnek kodu } & \multirow[b]{2}{*}{ KM } & \multirow[b]{2}{*}{ Katk1 } & \multicolumn{3}{|c|}{ Mikrobiyolojik sonuçlar (log kob g-1) } \\
\hline & & & MRS Agar & M17 Agar & $\begin{array}{c}\text { Kanamisin Eskulin } \\
\text { Azid Agar }\end{array}$ \\
\hline 1 & 20 & Kontrol & 2.3 & - & - \\
\hline 2 & 20 & Bakteri & 5.57 & - & - \\
\hline 3 & 20 & Bakteri & 5.6 & - & - \\
\hline 4 & 20 & Formik asit & 2.3 & - & - \\
\hline 5 & 20 & Formik asit & 2.2 & - & - \\
\hline 6 & 30 & Kontrol & 6.78 & - & 3.3 \\
\hline 7 & 30 & Bakteri & 7.36 & 2.1 & 4.2 \\
\hline 8 & 30 & Bakteri & 7.4 & - & 4.03 \\
\hline 9 & 30 & Formik asit & 6.7 & - & - \\
\hline 10 & 30 & Formik asit & 6.85 & - & 2.7 \\
\hline 11 & 40 & Kontrol & 7.47 & - & 2.65 \\
\hline 12 & 40 & Bakteri & 7.9 & - & 2.95 \\
\hline 13 & 40 & Bakteri & 7.92 & - & 2.23 \\
\hline 14 & 40 & Formik asit & 3.95 & 1.6 & 3.02 \\
\hline 15 & 40 & Formik asit & 4.2 & - & 2.66 \\
\hline
\end{tabular}


$4.0 \log$ kob $\mathrm{g}^{-1}$ 'a kadar düşürdüğünü tespit etmişlerdir. Kuru madde içeriğine bağlı olarak Kanamycin Esculin Azide Agar'da üreyen bakteri sayılarında da farklılık görülmektedir. Buna göre \% 20 KM içeriğine sahip silaj örnekleri Kanamycin Esculin Azide Agar'a ekildiklerinde üreme saptanamazken, \% 30 ve \% 40 KM içeriğine sahip silaj örneklerinde yaklaşık 2 log kob $\mathrm{g}^{-1}$ bakteri ürediği tespit edilmiştir (Tablo 2). Bu sonuçlar, \% $20 \mathrm{KM}$ içerikli silaj örneklerinde Enterococcus sayısının sayılabilecek sınırların altında olduğunu, diğer örneklerde de çok yüksek seviyelerde olmadığını göstermektedir. Marciňáková ve ark. (2008), E. faecium EF9296 suşlarının silaj inokulantı olarak kullandığı çalışmasında, oldukça kaliteli silaj elde ettiklerini, silaj pH'sının çok hızlı bir şekilde düştüğünü, silaj içeriğindeki laktik asit konsantrasyonun yüksek, asetik ve bütirik asit konsantrasyonunun düşük olduğunu rapor etmişlerdir. Çalışmamızda \% $20 \mathrm{KM}$ içeren silaj örneklerinde (kontrol grubu da dâhil) Enterococcus sayısı sayılabilir limitler altında iken (Tablo 2); $\% 30$ ve \% 40 KM içerikli örneklerde Enterococcus sayısının artmasına paralel olarak silaj kalitesinin de artmas1, silaj kalitesi üzerine Enterococcus sayısının da etkili olabileceğini düşündürmektedir.

Bu çalışmada \% $30 \mathrm{KM}$ içeren karabuğday silajı hazırlamada Lactobacillus buchneri LN463, ATCC PTA-2494, Lactobacillus plantarum LP 286, DSM 4784 ATCC 53187, Enterococcus faecium EF301 DSM 4789 ATCC 55593 kombinasyonu kullanılması nedeniyle inokulant kullanılan örneğin pH'sı kontrol grubuna göre daha düşük olduğu saptanmıştır. Filya ve Sucu (2007) buğday silajı ile ilgili yaptıkları çalışmada; \% $35.5 \mathrm{KM}$ içeren buğday örneklerinde başlangıç pH'ları 6.52 iken, L. plantarum, L. buchneri, Propionibacterium acidipropionici ve formik asit uygulanan gruplarda sırasıyla $\mathrm{pH}$ değerlerinin 3.96, 4.67, 4.55 ve 3.94 olarak tespit etmişlerdir.

\subsection{Karabuğday silajı örneklerinden izole edilen laktik asit bakterilerinin DNA parmak izi profilleri}

MRS Agar, M17 Agar ve Kanamycin Esculin Azide Agar besiyerlerinin yüzeyinde üreyen, grampozitif ve katalaz negatif sonuç veren izolatlar saflaştırılmıştır. Elde edilen saf izolatların her birisi kodlanarak toplam 50 adet izolat üzerinde gerçekleştirilen DNA parmak-izi çalışması ile karabuğday silaj örneklerinin LAB çeşitliliği tespit edilmeye çalışılmıştır. (GTG)5 ve M13 primerlerinin analizleri ile elde edilen tüm bantlar, ikili veri matrisi oluşturmak amaciyla pozisyonlarda mevcut (1) veya yok (0) olarak skorlanmıştır. Her primer örnek kombinasyonu en az iki farklı PZR amplifikasyonu tekrarlanmış ve sadece tekrarlanabilir bantlar değerlendirilmiştir. İzolatların genetik profillerini analiz etmek için (GTG)5 ve M13 uygunluğunu değerlendirmek için markörlerin performansı değerlendirilmiştir. Çalışmada kullanılan 50 izolat için M13 primeri ile toplamda 52 lokus (GTG)5 primeri ile 50 izolat için toplamda 39 lokus üretilmiştir (Tablo 3). Markör sistemi, farklı LAB türlerine ait izolatlar arasında önemli bir değişkenlik sağlayan çok sayıda fragment üretmiştir (Şekil 1-6).

Tablo 3. Çalışmada kullanılan (GTG)5 ve M13 markörlerine ait bilgiler

\begin{tabular}{llccc}
\hline Primer & $\begin{array}{l}\text { Primer sekans1 } \\
\left(5^{\prime}-3^{\prime}\right)\end{array}$ & TB & PB & $\begin{array}{l}\text { PPB } \\
(\%)\end{array}$ \\
\hline GTG5 & $\begin{array}{l}\text { GTGGTGGTG } \\
\text { GTGGTG }\end{array}$ & 39 & 23 & 58.9 \\
\hline M13 & $\begin{array}{l}\text { GAGGGTGG } \\
\text { CGGTTCT }\end{array}$ & 52 & 40 & 76.9 \\
\hline
\end{tabular}

TB: Toplam bant sayısı, PB: Polimorfik bant sayısı, PPB: Polimorfik bant yüzdesi

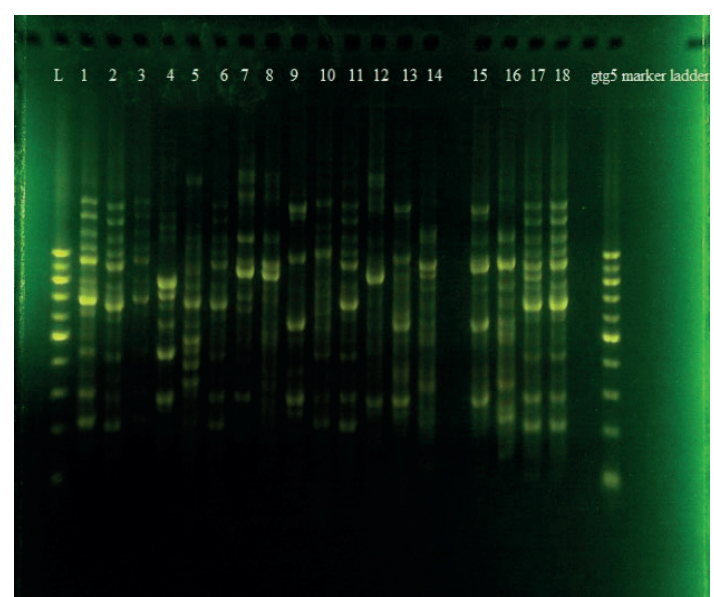

Şekil 1. Farklı silaj örneklerinden izole edilen 1 ile 18 arası kodlu laktik asit bakterilerinin (GTG)5 parmakizi profili

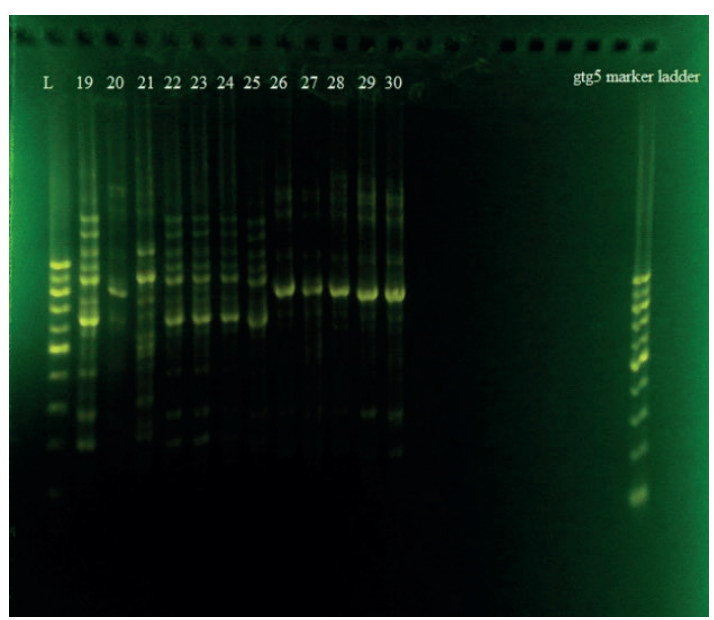

Şekil 2. Farklı silaj örneklerinden izole edilen 19 ile 30 arası kodlu laktik asit bakterilerinin (GTG)5 parmak-izi profili 


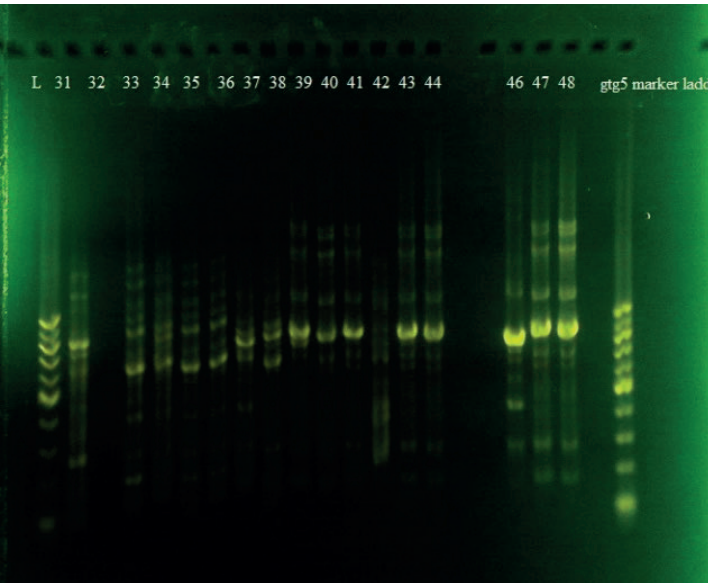

Şekil 3. Farklı silaj örneklerinden izole edilen 31 ile 48 arası kodlu laktik asit bakterilerinin (GTG)5 parmak-izi profili

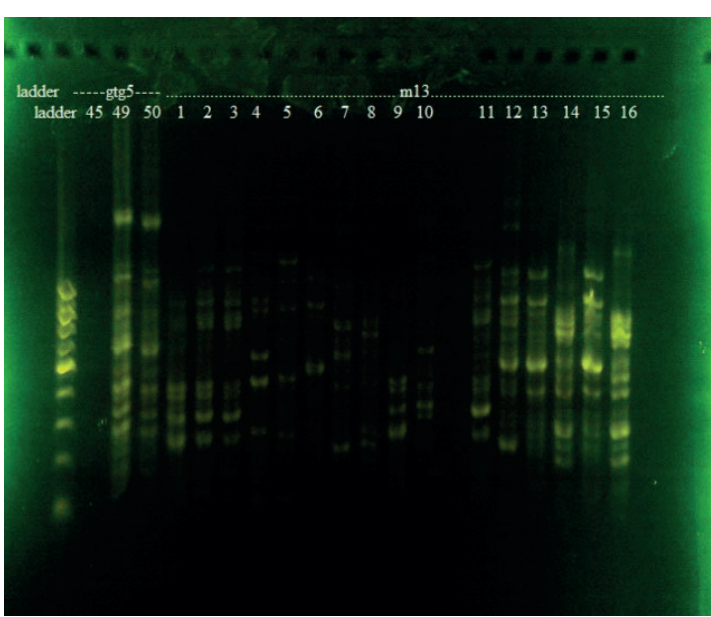

Şekil 4. Farklı silaj örneklerinden izole edilen 1 ile 16 arası kodlu laktik asit bakterilerinin $\mathrm{m} 13$ parmak-izi profili

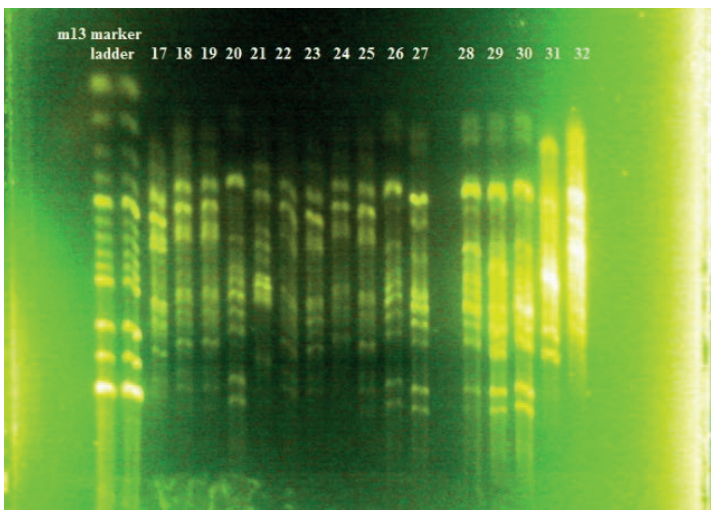

Şekil 5. Farklı silaj örneklerinden izole edilen 17 ile 32 arası kodlu laktik asit bakterilerinin m13 parmakizi profili

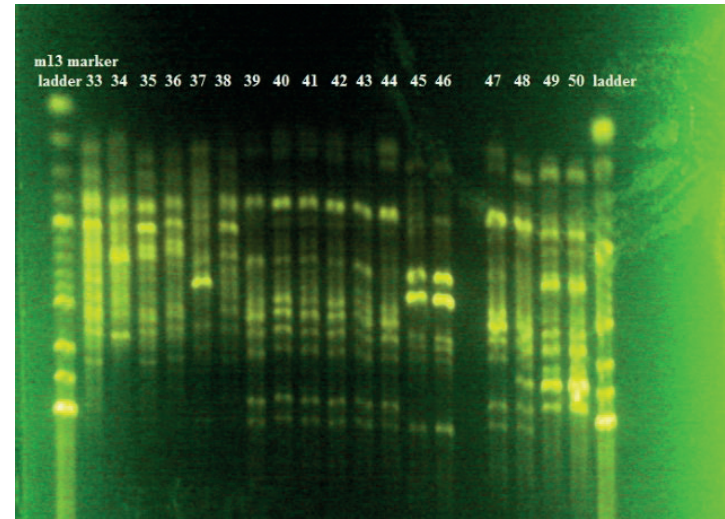

Şekil 6. Farklı silaj örneklerinden izole edilen 33 ile 50 arası kodlu laktik asit bakterilerinin m13 parmakizi profili

LAB izolatlarının (GTG)5 primeri ile \% 80 benzerlik katsayısına göre bir tekli tip ve 4 küme içerisinde olmak üzere toplam 5 farklı genotip (G1, G2, G3, G4 ve G5) içerisinde gruplandığ belirlenmiştir. Bu genotiplerin sırasıyla 19, 9, 2, 14 ve 6 izolat içerdiği, G1 no'lu genotipin baskın genotip olduğu saptanmıştır (Şekil 7). En fazla suş çeşitliliğine \% $30 \mathrm{KM}$ içeren hammaddeden elde edilen silajlarda rastlanırken, en az çeşitliliğin ise \% 20 KM içeren hammaddeden elde edilen silajlarda olduğu saptanmıştır.

LAB izolatlarının M13 primeri ile \% 80 benzerlik katsayısına göre bir tekli tip ve 6 küme içerisinde olmak üzere toplam 7 farklı genotip (M1, M2, M3, M4, M5, M6 ve M7) içerisinde gruplandığ 1 belirlenmiştir. Bu genotiplerin sırasıyla 19, 14, 6,1,3,2 ve 5 izolat içerdiği, M1 no'lu genotipin baskın genotip olduğu saptanmıștır (Şekil 8). M13-DNA fragment profillerinin ayrim gücünün (GTG)5-DNA fragmentlerine göre daha yüksek olduğu tespit edilmiştir.

Santos ve ark. (2019)'nın M13 ve (GACA)4 primerlerini kullanarak yapmış oldukları çalışmalarında, M13 primeri ile elde edilen DNAparmakizi profilinin ayrım gücünün (GACA)4 kullanılarak yapılandan daha yüksek olduğunu tespit etmişlerdir. Turkoya ve ark. (2012), (GACA)4 primeri ile LAB izolatları arasındaki farklılı̆̆ açıkça ortaya koymak zor iken, M13 parmakizi profili ile izolatların intraspesifik farklılıklarını ortaya koymada kullanışlı olduğunu rapor etmişlerdir.

Yukarıda yapılan çalışmaların sonuçları bizim DNA-parmakizi profili çalışmamızın sonuçları ile paralellik göstermektedir. M13-DNA fragment profillerinin ayrım gücünün (GTG)5-DNA 


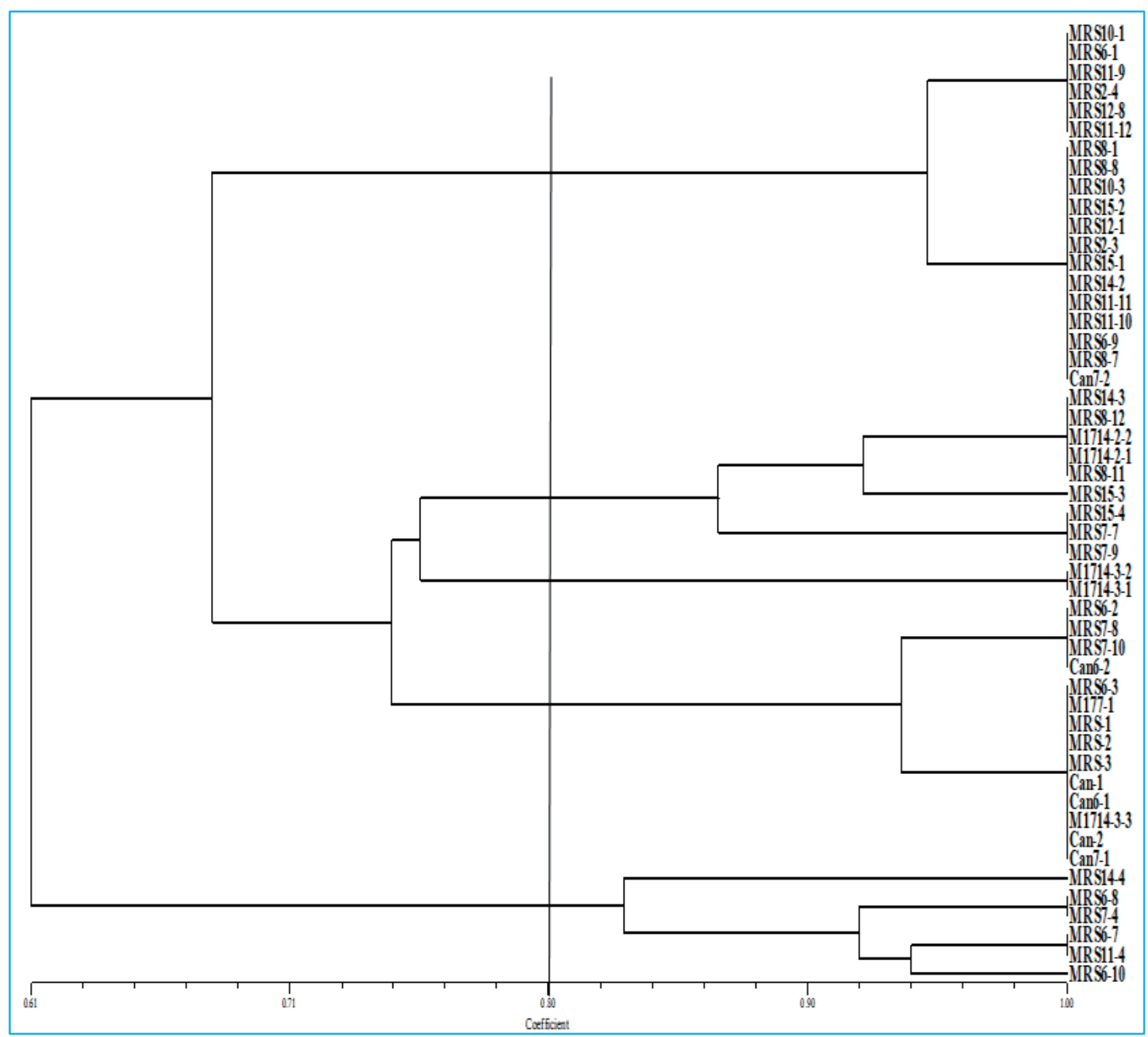

Şekil 7. 50 izolat için (GTG)5 primeri ile veri matrisine dayalı UPGMA ağacı

fragmentlerine göre daha yüksek olduğu tespit edilmiştir. Örneğin; 37 (MRS8-11) no'lu izolatın (GTG)5-DNA fragment profili 31 ya da 45 no'lu izolatların (GTG)5-DNA fragment profilleri ile aynı olsa da, aynı örneğin M13-DNA fragment profili diğer bütün izolatların fragment profillerinden farklı olduğu tespit edilmiştir.

$\mathrm{Bu}$ nedenle tek tekrarlı dizi profili LAB çeşitliliğini ortaya koyma konusunda yeterli değildir. En az iki farklı tekrarlı dizi profili incelenerek bakteri çeşitliliğine karar vermek sonuçların güvenirliliğini arttıracaktır. Ayrıca sonuçlara göre LAB izolatlarının gruplandırılmasinda M13 DNA parmakizi profillerinin elde edilmesi hılı ve alternatif bir metot olduğu görülmektedir.

\section{Sonuçlar}

Karabuğday silajının kalite ve LAB çeşitliliğinin incelendiği bu araştırmada, \% $30 \mathrm{KM}$ içeriğinin ve Enterococcus sayısının silaj kalitesinde önemli olduğu tespit edilmiştir. İki farklı primer [M13, (GTG)5] kullanılarak yapılan LAB çeşitliliği incelemesinde farklı bant profili elde edilmiştir. $\mathrm{Bu}$ araştırma karabuğday silajının LAB profilinin daha iyi anlaşılmasına ve gelecekte yapılacak bilimsel çalışmalara katkı sağlayacaktır. Yapılan analizler ve incelemeler sonucunda, 33 ve 34 no'lu izolatların hem \% 30 hem de \% 40 kuru maddeli silaj örneklerinde yer alması ve baskınlıkları nedeniyle, bu izolatlar yeni inokulant kombinasyonu hazırlamada kullanılabilecek suşlardır. Ayrıca elde edilen izolatların yeni çalışmalara silaj starteri olarak katkı sağlayacağı söylenebilir.

\section{Teşekkür}

$\mathrm{Bu}$ çalışma, Türkiye Bilimsel ve Teknolojik Araştırma Kurumu (TÜBİTAK) tarafından 2209A-Üniversite Öğrencileri Yurt İçi Araştırma Projeleri Destekleme Programı kapsamında desteklenmiştir. 


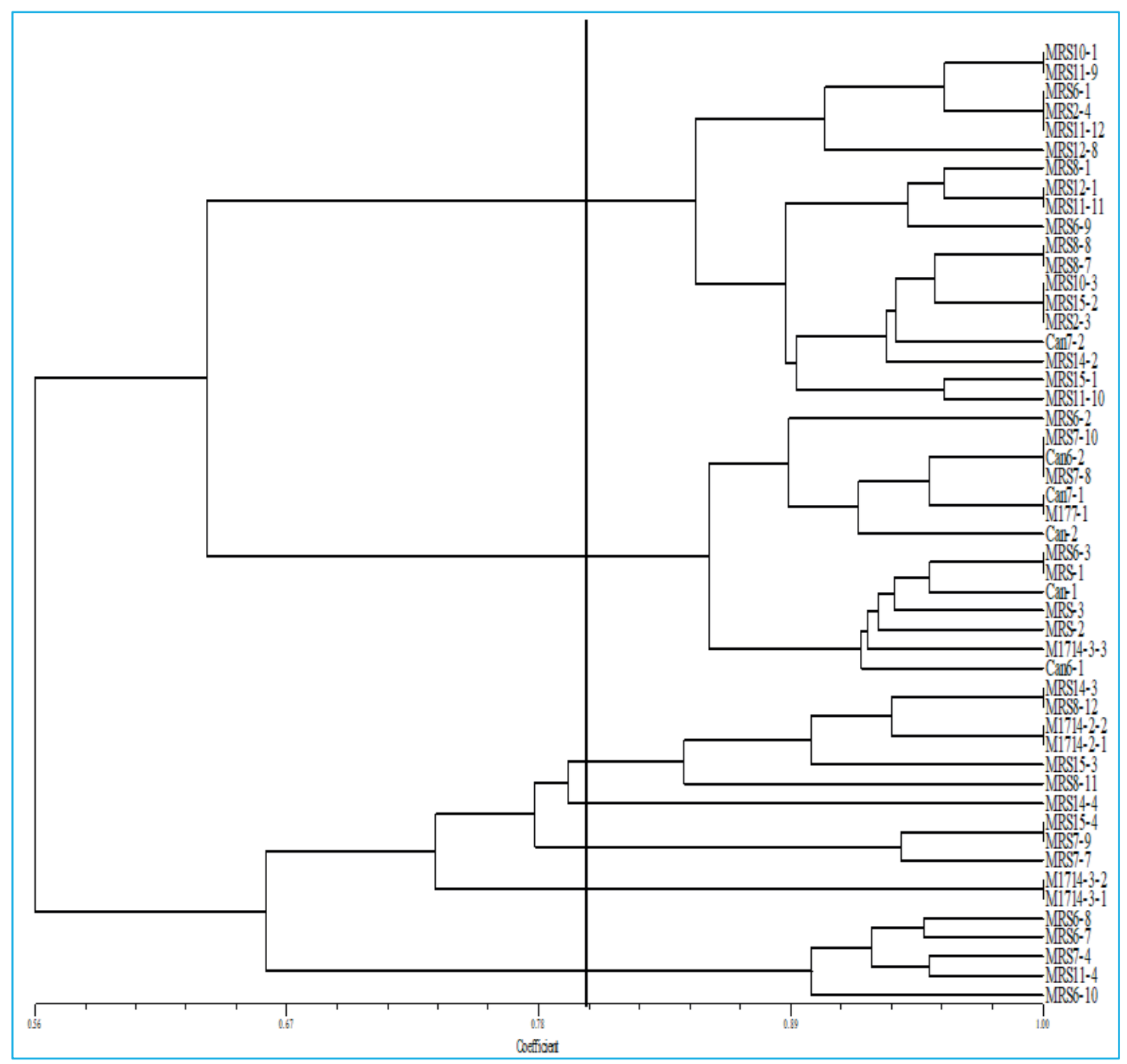

Şekil 8. 50 izolat için M13 primeri ile veri matrisine dayalı UPGMA ağacı

\section{Kaynaklar}

Aky1ld1z, R., 1984. Yemler Bilgisi Laboratuvar Kilavuzu. Ankara Üniversitesi Ziraat Fakültesi Yayınları, No: 358, Ankara.

Alçiçek, A., Tarhan, F., Özkan, K., Adışen, F., 1999. İzmir ili civarında bazı süt sığırcılığı işletmelerinde yapılan silo yemlerinin besin madde içeriği ve silaj kalitelerinin saptanması üzerine bir araştırma. Hayvansal Üretim Dergisi, 39-40: 54-63.

Altınok, S., Genç, A., Erdoğdu, İ., 2005. Farklı ekim şekillerinde yetiştirilen mısır ve soyadan elde edilen silajlarda kalite özelliklerinin belirlenmesi. Türkiye VI. Tarla Bitkileri Kongresi, 5-9 Eylül, Antalya, Cilt II, s. 1011-1016.

Amelchanka, S.L., Kreuzer, M., Leiber, F., 2010. Utility of buckwheat (Fagopyrum esculentum Moench.) as feed: Effects of forage and grain on in vitro ruminal fermentation and performance of dairy cows. Animal Feed Science and Technology, 155(2-4): 111-121.

Arslan, M., Çakmakçı, S., 2011. Mısır (Zea mays) ve sorgumun (Sorghum bicolor) farklı bitkilerle birlikte yapılan silajlarının karşılaştırılmaları. Akdeniz Üniversitesi Ziraat Fakültesi Dergisi, 24(1): 47-53.

Bingöl, N.T., Karslı, M.A., Bolat, D., Akça, İ., 2008. Vejetasyonun farkl1 dönemlerinde hasat edilen korungaya ilave edilen melas ve formik asit' in silaj kalitesi ve in vitro kuru madde sindirilebilirliği üzerine etkileri. Yeni Yüzyll Üniversitesi Veteriner Fakültesi Dergisi, 2: 61-66.

Bulut, C., 2003. Isolation and characterization of lactic acid bacteria from cheese. Yüksek Lisans Tezi, İzmir Yüksek Teknoloji Enstitüsü, İzmir.

Dumlu, G.Z., Fayetörbay, D., Tan, M., 2013. Effects of some additives, harvest stage and wilting on alfalfa silage. Atatürk Universty Journal of the Agricultural Faculty, 46(2): 113-118.

Eliş, S., Özyazıcı, M.A., 2019. Determination of the silage quality characteristics of different switchgrass (Panicum virgatum L.) cultivars. Applied Ecology and Environmental Research, 17(6): 15755-15773.

Fabiszewska, A.U., Zielińska, K.J., Wróbel, B., 2019. Trends in designing microbial silage quality by 
biotechnological methods using lactic acid bacteria inoculants: a minireview. World Journal of Microbiology and Biotechnology, 35(5): 76.

Filya, İ., 2001. Silaj Teknolojisi. Alltech Bilimsel Yayınlar Serisi, Hakan Ofset, İzmir.

Filya, İ., 2002a. Laktik asit bakteri ve laktik asit bakteri+enzim karısımı silaj inokulantlarının mısır silaj1 üzerine etkileri. Turkish Journal of Vetenary and Animal Science, 26(3): 679- 687.

Filya, İ., 2002b. Laktik asit bakteri inokulantlarının mısır ve sorgum silajlarının fermantasyon, aerobik stabilite ve in situ rumen parçalanabilirlik özellikleri üzerine etkileri. Turkish Journal of Vetenary and Animal Science, 26(4): 815-823.

Filya, İ., Ashbell, G., Hen, Y., Weinberg, Z.G., 2000. The effect of bacterial inoculants on the fermentation and aerobic stability of whole crop wheat silage. Animal Feed Science and Technology, 88(1-2): 39-46.

Filya, İ., Sucu, E., 2004. Formik asit temeline dayalı bir koruyucunun misır ve sorgum silajlarının aerobik stabiliteleri üzerine etkisi. 4. Ulusal Zootekni Bilim Kongresi, Bildiriler kitabı, 1-3 Eylül, Isparta, s. 424428.

Filya, İ., Sucu, E., 2007. The effect of bacterial inoculants and a chemical preservative on the fermentation and aerobic stability of whole-crop cereal silages. AsianAustralian Journal Animal Science, 20(3): 378-384.

Harrigan, W.F., McCance, M.E., 1976. Basic methods. In: W.F. Harrigan (Ed.), Laboratory Methods in Food and Dairy Microbiology, Revised Edition, Academic Press, London, pp. 3-16.

Henderson, A.R., McDonald, P., 1984. The effect of a range of commercial inoculants on the biochemical changes during the ensilage of grass in laboratory studies. Research of Development in Agricultural, 3: 167-171.

Hounhouigan, D.J., Nout, M.J.R., Nago, C.M., Houben, J.H., Rombouts, F.M., 1993. Characterization and frequency distribution of species of lactic acid bacteria involved in the processing of maw, a fermented maize dough from Benin. International Journal of Food Microbiology, 18: 279-287.

Kara, B., Ayhan, V., Akman, Z., Adiyaman, E., 2009. Determination of silage quality, herbage and hay yield of different triticale cultivars. Asian Journal of Animal Vetenary Advence, 4(3): 167-171.

Keleş, G., Kocaman, V., Üstündağ, A.Ö., Zungur Bastıoğlu, A., Özdoğan, M., 2018. Growth rate, carcass characteristics and meat quality of growing lambs fed buckwheat or maize silage. AsianAustralasian Journal of Animal Sciences, 31(4): 522528.

K1lıç, A., 1986. Silo Yemi. Bilgehan Basımevi, İzmir.

Leiber, F., Kunz, C., Kreuzer, M., 2012. Influence of different morphological parts of buckwheat (Fagopyrum esculentum) and its major secondary metabolite rutin on rumen fermentation in vitro. Czech Journol of Animal Science, 57(1): 10-18.
Li, W., Raoult, D., Fournier, P.E., 2009. Bacterial strain typing in the genomic era. FEMS Microbiology Reviews, 33(5): 892-916.

Marciňáková, M., Lauková1, A., Simonová1, M., Strompfová1, V., Koréneková, B., Nad, P., 2008. A new probiotic and bacteriocin-producing strain of Enterococcus faecium EF9296 and its use in grass ensiling. Czech Journal of Animal Science, 53(8): 336-345.

McAllister, T.A., Dunière, L., Drouin, P., Xu, S., Wang, Y., Munns, K., Zaheer, R., 2017. Silage review: Using molecular approaches to define the microbial ecology of silage. Journal of Dairy Science, 101(5): 4060-4074.

Meeske, R., Basson, H.M., Cruywagen, C.W., 1999. The effects of a lactic acid bacteria inoculant with enzymes on the fermantation dynamics, intake and digestibility of digitaria eriantha silage. Animal Feed Science Technology, 81(3-4): 237-248.

Merry, R.J., Cussen, R.F., Mackenna, A.P., Willıams, J., Tweed, S., 1993. The effect of different inoculants on fermentation and proteolsis in silages of differing perrinial ryegrass and white clover content. Proceedings of the 10th International Silage Conference, September 6-8, Dublin, pp. 83-84.

Moran, J., Weinberg, Z.G., Ashbell, G., Hen, Y., Owen, T.R., 1996. The effects of bacterial inoculant on the fermantation and aerobic stability of whole crop wheat silage. Proceedings of the 11th International Silage Conference, September 8-11, Aberystwyth, pp. 164-165.

Muck, R.E., 2004. Effect of corn silage inoculants on aerobic stability. American Society of Agricultural Engineers, 47(4): 1011-1016.

Özkan, U., 2020. Türkiye yem bitkileri tarımına karşılaştırmalı genel bakış ve değerlendirme. Turkish Journal of Agricultural Engineering Research, 1(1): $29-43$.

Özyazıcı, M.A., Turan, N., Açıkbaş, S., 2018. İkinci ürün olarak yetiştirilen bazı sorgum, sudanotu, sorgum $\mathrm{x}$ sudanotu melezi ve mısır çeşitlerinin silaj kalitelerinin belirlenmesi. UMTEB III. Uluslararast Mesleki ve Teknik Bilimler Kongresi, 21-22 Haziran, Tam Metin Kitab1, Cilt-6, Gaziantep, Türkiye, s. 3898-3907.

Rohlf, F.J., 2000. NTSYS-pc: Numerical Taxonomy and Multivariate Analysis System. Version 2.1, Exeter Software Setauket, New York.

Santos, A., Ávila, C., Soares, C., Carvalho, B.F., Schwan, R.F., Lima, N., 2019. Lactic acid bacteria diversity in corn silage produced in Minas Gerais (Brazil). Annals of Microbiology, 69: 1445-1459.

Stokes, M., Chen, J., 1994. Effects of an enzymeinoculant mixture on the course of fermentation of corn silage. Journal of Dairy Science, 77: 3401-3409.

Tan, M., Serin, Y., 2008. Silaj yapım tekniği. Y. Serin (Ed.), Yem Bitkileri ve Meraya Dayalı Hayvancılık Eğitimi, Erciyes Üniversitesi Yayınları, Kayseri, s. 271-286. 
Vandamme, P., Bruyne, K., Pot, B., 2014. Phylogenetics and systematics. In: W.H. Holzapfel, B.J.B. Wood (Eds.), Lactic Acid Bacteria-Biodiversity and Taxonomy, Wiley, Chichester, pp. 31-45.
Weinberg, Z.G., Ashbell, G., Azrieli, A., Brukental, I., 1993. Ensiling peas, ryegrass and wheat with additives of lactic acid bacteria (LAB) and cell wall degrading enzymes. Grass and Forage Science, 48(1): 70-78. 